Acta vet. scand. $1978,19,574-587$.

From the Department of Food Hygiene, Veterinary College of Norway, Oslo, and the Veterinary Institute, Oslo, Norway.

\title{
TOXOPLASMA GONDII IN SWINE IN SOUTH-EASTERN NORWAY
}

\author{
By \\ Ivar Hellesnes, Svein Fredrik Mohn and Brynjulf Melhuus
}

\begin{abstract}
HELLESNES, I., S. F. MOHN and B. MELHUUS: Toxoplasma gondii in swine in south-eastern Norway. Acta vet. scand. 1978, 19, 574-587. - A total of 407 swine bred in south-eastern Norway have been tested for the presence of Toxoplasma gondii antibodies in serum by use of the dye-test, and diaphragm muscle from all sero-positive and some sero-negative swine has been tested for the presence of mouse-infective cysts.

The prevalence of antibodies was as low as $10.1 \%$. The prevalence increased with the weight of the swine, but apparently with a decline after passing a weight of $140 \mathrm{~kg}$. Only dye-test titres up to 50 were found. The prevalence of dye-test positive swine was higher in small herds $(<300$ swine p.a.) than in larger ones $(>300$ swine p.a. $)$. The prevalence of herds with dye-test positive swine in the region surrounding the Oslo-fjord was higher in the coastal than in the inland zone. The incidence of infection was the same during the summerautumn period as during the winter-spring period. Toxoplasma was recovered from the diaphragm muscle of about $2 / 3$ of the dye-test positive swine. Parasites were isolated from some pigs with a dye-test titre of 4 , and from all the pigs with a titre of 50 . Toxoplasma was not isolated from dye-test negative swine. The epidemiological and food-hygienic significance of porcine toxoplasmosis in Norway is discussed according to the present results.
\end{abstract}

toxoplasma infection; epidemiology; food hy giene; swine.

Porcine toxoplasmosis was first reported in USA (Farrell et al. 1952), and Momberg-J $\phi r g e n s e n ~(1956)$ gave the first description of Toxoplasma gondii (Toxoplasma) in swine in Scandinavia. Both reports dealt with clinical outbreaks.

As in most domestic animals and man, Toxoplasma infection in swine is usually subclinical. Serological surveys are therefore useful for estimating the prevalence in a population, and for giving information on the parasite's epidemiology. The dye-test (Sabin \& Feldman 1948) has been used most frequently in serological surveys. Several surveys of the prevalence of Toxoplasma 
antibodies in swine have been reported (for review, see Boch et al. $1964 \mathrm{~b}$ ), and the prevalence seems to vary considerably. Rawal (1959) found $12 \%$ positive (dye-test titre $\geq 4$ ) out of 100 swine in Great Britain, while Boch et al. (1964 b) found $97.6 \%$ positive (dye-test titre $\geq 4$ ) among 500 swine in Germany.

After a primary infection, Toxoplasma develops cysts in different organs of the attacked organism. In living tissues, the cysts can remain infective for meat-eating animals for years, and this may be an important factor in the transmission of the parasite. Fed to cats, cysts in tissues will consistently produce oocysts in the cat faeces (Dubey et al. 1970).

Toxoplasma in man may give rise to various clinical manifestations, of which abortion and congenitally acquired infection in the central nervous system seem to be the most important. Both the oocyst and the cyst are possible initiators of Toxoplasma infection in humans, but their relative significance in the epidemiology of toxoplasmosis in humans is debated.

The demonstration of Toxoplasma cysts in pork has been reported by many workers (Jacobs et al. 1960, Boch et al. $1964 \mathrm{~b}$, Work 1967 and Weisstanner 1969). However, the percentage of cyst-positive swine among the sero-positive ones varies considerably.

The aim of this investigation, which is the first on toxoplasmosis in swine in Norway, was to study the epidemiological and food-hygienic significance of porcine toxoplasmosis. For this purpose we wanted to:

A. obtain information about the prevalence of Toxoplasma antibodies in swine

1. of different weight

2. from herds of different sizes

3. from different geographical zones

4. bred during both the summer-autumn and the winterspring periods

B. determine the prevalence of Toxoplasma cysts in the swine diaphragm and its relation to sero-positivity.

\section{MATERIALS AND METHODS}

In the period from Sept. 1972 to Sept. 1973 a total of 407 swine slaughtered at "Fellesslakteriet" in Oslo were examined. The swine had been bred in $\mathbf{1 1 5}$ herds. 
Part 1 comprises 194 swine. The samples were collected on 10 occasions from Sept. to Dec. 1972.

Part 2 comprises 200 swine. The samples were collected on 8 occasions from May to July 1973.

Part 3 comprises 13 swine slaughtered in Sept. 1973.

\section{Collection of blood and muscle samples}

Blood samples were collected in sterile glass tubes during the bleeding process, while samples of the diaphragm muscle from the corresponding animals were obtained later in the slaughtering process.

As diaphragm muscle evidently contains cysts at least as frequently as other striated muscles (Boch et al. 1964 a), this muscle was chosen for parasitological testing. The muscle samples were kept in plastic bags at $4^{\circ} \mathrm{C}$ until the results of the serological testing were known. The storage time varied from 2 to 11 days with an average of 5 days.

Samples were collected on different week-days and at different times of the day. For practical reasons, however, the samples taken during 1 day were in succession.

\section{Information about the swine}

Information obtained about the swine was: dressed weight, the address of the supplying farm and the total amount of swine delivered from each farm to the slaughter-house during the year.

Swine with dressed weights from 60 to $80 \mathrm{~kg}$ were represented by 299 animals delivered from 78 herds. The ages of the 60 to $80 \mathrm{~kg}$ swine were about 5 to 7 months. Probably, nearly all the animals weighing $>100 \mathrm{~kg}$ were sows which had had 1 or more pregnancies.

\section{Geographical grouping of the herds}

The geographical grouping of the herds was done according to the postal number of the farms' addresses (Postdirektoratet 1972). Herds from the districts along the northern and eastern side of the Oslo-fjord were recorded in 1 group called "coastal", and herds from the neighbouring, inland districts were grouped as "inland". The width of the coastal zone is about 12 to $25 \mathrm{~km}$. 
Serological examinations of the swine

All blood samples were examined by the dye-test (Sabin \& Feldman 1948). The sera were inactivated for $30 \mathrm{~min}$. at $56^{\circ} \mathrm{C}$. The titres reported are the reciprocal values of the highest serum dilutions showing a positive reaction, i.e. $\geq 50 \%$ unstained, morphologically altered trophozoites. Dilution $1: 4$ is the undiluted mixture of serum, activator and mouse exudate.

Parasitological examinations of dye-test positive swine

Samples from all dye-test positive swine in Parts 1 and 2 were examined for the presence of Toxoplasma cysts.

The diaphragm samples, trimmed for fat and fascia, weighed from 55 to $110 \mathrm{~g}$ with an average weight of $101 \mathrm{~g}$. Isolation of cysts was done principally according to the peptic digestion technique developed by Jacobs et al. (1960), as modified by Work (1967).

The main differences between our procedure and the original one are the use of a meat mincer (Atomixer) instead of an ordinary household-type meat grinder to grind the diaphragm specimens, and the use of a weaker pepsin type, 1:2000 (Orthana 502119 ) instead of $1: 10,000$.

The sediment from the digestion procedure was resuspended in saline to a volume of $6 \mathrm{ml}$ and inoculated parenterally into 6 mice.

After at least 8 weeks the mice were killed and their brains were examined for cysts of Toxoplasma. The brains were ground with $1 \mathrm{ml}$ saline in a mortar, and smears were prepared for microscopic examinations at $100 \times$ magnification. Nine drops were examined from each brain suspension.

In Parts 2 and 3, blood samples from the mice were obtained by heart puncture. Coagulated blood in the chest lumen was also collected. The dye-test was performed, and titres $\geq 10$ were regarded as positive. Subinoculations were not made, as it has been shown by Siim (1961) that this does not lead to more positive reactions.

Mice that died spontaneously during the experiment were not examined.

Parasitological examinations of dye-test negative swine

Isolation of Toxoplasma was attempted on material from 30 individual dye-test negative swine from Part 2. Diaphragm 
muscles from 25 swine were divided into groups of $5,100 \mathrm{~g}$ from each specimen were thoroughly mixed after grinding, and $1 / 5$ of the mixture was used for the digestion procedure. Isolation of cysts was also attempted with material from 5 single dye-test negative swine.

The mice inoculated with material from dye-test negative swine were only examined serologically.

\section{Controls}

For every 6 mice used for inoculation, 1 mouse was kept separately as a control for possible spontaneous infection.

\section{Climatological data}

Data of the climatic conditions in south-eastern Norway were obtained from the Norwegian Meteorological Institute (1967, 1975).

\section{Statistics}

The statistical Fisher-Irwin test for 2-by-2 tables and the Wilcoxon 2 samples test were performed as described by Hodges \& Lehmann (1970). Significance probabilities with values lower than $5 \%(\mathrm{P}<0.05)$ were regarded as significant.

\section{RESULTS}

The results of the serological examinations of the 407 swine are presented in Table 1. The swine are grouped according to

T a ble 1. Results of the serological examination of 407 swine grouped according to carcass weight using the dye-test.

\begin{tabular}{ccrrr}
\hline & \multicolumn{4}{c}{$\begin{array}{c}\text { Number of animals } \\
\text { with dye-test titre }\end{array}$} \\
\cline { 3 - 5 } $\begin{array}{c}\text { Carcass weight } \\
\text { in kg }\end{array}$ & $\begin{array}{c}\text { Total number } \\
\text { of animals }\end{array}$ & $<4$ & $\geq 4$ & $\begin{array}{c}\text { Percentage of dye-test } \\
\text { positive }(\geq 4)\end{array}$ \\
\hline$<60$ & 32 & 30 & 2 & 6.3 \\
$60-80$ & 299 & 279 & 20 & 6.7 \\
$80-100$ & 31 & 28 & 3 & 9.7 \\
$100-120$ & 8 & 4 & 4 & 50.0 \\
$120-140$ & 17 & 9 & 8 & 47.1 \\
$140-160$ & 12 & 10 & 2 & 16.7 \\
$>160$ & 8 & 6 & 2 & 25.0 \\
\hline Total & 407 & 366 & 41 & 10.1 \\
\hline
\end{tabular}


weight at $20 \mathrm{~kg}$ intervals. The bulk of the specimens, $73 \%$, weighed between 60 and $80 \mathrm{~kg}$.

The overall prevalence of Toxoplasma antibodies was $10.1 \%$ (titre $\geq 4$ ). There was a significant difference in the prevalence of Toxoplasma antibodies between swine weighing $<100 \mathrm{~kg}$ and those weighing $\geq 100 \mathrm{~kg}(\mathrm{P}<0.0001)$. No other significant difference between the groups was found. The prevalence of Toxoplasma antibodies among swine $>140 \mathrm{~kg}$ was lower $(16.7$ to $25.0 \%$ ) than among swine weighing between 100 and $140 \mathrm{~kg}$ (50.0 to $47.1 \%)(\mathrm{P}=\mathbf{0 . 0 5 3})$.

As recorded in Table 2, only dye-test titres up to 50 were observed, and a titre of 4 was most often encountered (51\%). Titres $\geq 10$ were more frequent among swine weighing less than $80 \mathrm{~kg}$ than among the heavier ones $(P=0.079)$.

$\mathrm{T}$ a b l e 2. Dye-test titres in 41 positive swine grouped according to carcass weight.

\begin{tabular}{crccc}
\hline $\begin{array}{c}\text { Carcass weight } \\
\text { in kg }\end{array}$ & \multicolumn{5}{c}{ Number of swine with dye-test titre } \\
\cline { 2 - 5 } & $\geq 4$ & 4 & \multicolumn{1}{c}{10} & 50 \\
\hline$<80$ & 22 & $9(41 \%)$ & $7(32 \%)$ & $6(27 \%)$ \\
$>80$ & 19 & $12(63 \%)$ & $5(26 \%)$ & $2(11 \%)$ \\
\hline & 41 & $21(51 \%)$ & $12(29 \%)$ & $8(20 \%)$ \\
\hline
\end{tabular}

Data concerning the 299 swine weighing between 60 and 80 $\mathrm{kg}$ were used when the relation of dye-test positivity to herd size was examined. As shown in Table 3, dye-test positive swine were

$\mathrm{T}$ a b l e 3. Results of the serological examination of 78 swine herds grouped according to number of swine from each herd with carcass weight between 60 and $80 \mathrm{~kg}$, slaughtered during 1 year.

\begin{tabular}{cccc}
\hline $\begin{array}{c}\text { Number of swine, } \\
60-80 \mathrm{~kg} \\
\text { delivered during } \\
\text { 1 year }\end{array}$ & $\begin{array}{c}\text { Number of } \\
\text { herds }\end{array}$ & $\begin{array}{c}\text { Number of herds } \\
\text { with dye-test } \\
\text { positive swine }\end{array}$ & $\begin{array}{c}\text { Average number of } \\
\text { swine examined from } \\
\text { each herd }\end{array}$ \\
\hline$<100$ & 34 & $7(21 \%)$ & 3.0 \\
$100-200$ & 22 & $5(23 \%)$ & 3.8 \\
$200-300$ & 10 & $2(20 \%)$ & 4.9 \\
$300-400$ & 4 & 0 & 5.8 \\
$400-500$ & 3 & 0 & 4.0 \\
$500-600$ & 3 & 0 & 6.3 \\
$>600$ & 2 & 0 & 5.5 \\
\hline Total & 78 & 14 & 3.8 \\
\hline
\end{tabular}


found in $14(21 \%)$ of 66 herds from which less than 300 swine were delivered during 1 year. Toxoplasma antibodies were not detected in serum from swine delivered from larger farms.

The prevalence of herds with dye-test positive swine (60 to $80 \mathrm{~kg}$ ) is listed in Table 4 according to geographical location. The prevalence of herds with dye-test positive swine was higher in the coastal zone $(30 \%)$ than in the inland zone $(13 \%)(\mathrm{P}=$ $0.064)$.

$\mathrm{T}$ a b l e 4. Swine herds in south-eastern Norway grouped according to the relation between their geographical location and the presence of Toxoplasma antibodies in the $60-80 \mathrm{~kg}$ swine.

\begin{tabular}{lccccc}
\hline $\begin{array}{l}\text { Geographical } \\
\text { location }\end{array}$ & $\begin{array}{c}\text { Number } \\
\text { of herds } \\
\text { examined }\end{array}$ & $\begin{array}{c}\text { Number of } \\
\text { herds with } \\
\text { dye-test } \\
\text { positive swine }\end{array}$ & $\begin{array}{c}\text { Percentage } \\
\text { of positive } \\
\text { herds }\end{array}$ & $\begin{array}{c}\text { Average } \\
\text { number } \\
\text { of swine } \\
\text { examined from } \\
\text { each herd }\end{array}$ & $\begin{array}{c}\text { Percentage of } \\
\text { the herds which } \\
\text { have delivered } \\
\begin{array}{c}300 \text { swine } \\
\text { during the year }\end{array}\end{array}$ \\
\hline coastal & 23 & 7 & 30 & 4.4 & $\begin{array}{c}13 \\
\text { inland }\end{array}$ \\
\hline 55 & 7 & 13 & 3.6 & $\begin{array}{c}\text { herds }) \\
16 \\
\text { (9 herds })\end{array}$ \\
\hline Total & 78 & 14 & 18 & & \\
\hline
\end{tabular}

The 299 swine weighing from 60 to $80 \mathrm{~kg}$ constitute a homogenous group, and their age was about 5 to 7 months. Thus, the 60 to $80 \mathrm{~kg}$ swine in Part 1 were bred during the summer and autumn months while the 60 to $80 \mathrm{~kg}$ swine in Part 2 were bred during the winter and spring months. The prevalence of Toxoplasma antibodies in the 2 groups was $6.5 \%$ and $6.9 \%$ among 154 and 145 swine, respectively.

The results of the parasitological examinations of dye-test positive swine are shown in Table 5. Isolation of Toxoplasma cysts was achieved in 20 of 33 cases, i.e. $61 \%$. The parasite was recovered from $39 \%$ of the swine with a dye-test titre of 4 , compared with $87 \%$ of those with higher titres $(P=0.006)$.

Parasitological examinations of dye-test negative swine did not result in the detection of Toxoplasma antibodies in any of the inoculated mice.

No evidence of Toxoplasma infection was found in the control mice. 
T a b l e 5. Isolation of Toxoplasma from the diaphragm muscle of dye-test positive swine.

\begin{tabular}{lrrrr}
\hline & \multicolumn{3}{c}{ Number of swine with } & Tye-test titre \\
\cline { 2 - 4 } & 4 & 10 & 50 & \\
\hline Number attempted & 18 & 10 & 5 & 33 \\
Number of isolations & 7 & 8 & 5 & 20 \\
Percentage of positive & 39 & 80 & 100 & 61 \\
\hline
\end{tabular}

(In addition, all mice inoculated with material from 1 swine with titre 4 and 1 with a titre of 50 died between the 2nd and 6 th day after inoculation).

\section{DISCUSSION}

Toxoplasma gondii is an ubiquitous parasite, and Toxoplasma antibodies have been reported in warm-blooded animals and man in all parts of the world, from the tropics to the Arctic (Feldman \& Miller 1956). However, the prevalence of Toxoplasma antibodies varies considerably. Serological surveys among swine also indicate considerable geographical differences in the prevalence. In the present survey an overall prevalence of $10.1 \%$ dye-test positive swine (titre $\geq 4$ ) was found. This is among the lowest reported in the literature. Other surveys conducted in northern European countries have been done by Folkers \& Perié (1963) who found $62.5 \%$ dye-test positive swine (titre $\geq 4$ ) in the Netherlands and Boch et al. (1964 b) who found $97.6 \%$ positive (titre $\geq 4$ ) in Germany, while Work (1971) detected $20.6 \%$ positive (titre $\geq 10$ ) in Denmark.

There seems to be a general trend that the prevalence of Toxoplasma antibodies in man and animals is higher in areas with a warm and moist climate than in colder and drier areas. The regions where the swine in the present study were raised have a rather cold winter climate with normal daily air temperatures of about $-5^{\circ} \mathrm{C}$ in January, being coldest in the inland zone. The summer climate is temperate, and the normal daily temperature in July is about 18 to $20^{\circ} \mathrm{C}$, being highest in the coastal zone. The annual precipitation in the region varies from $600 \mathrm{~mm}$ to 900 $\mathrm{mm}$, but with only minor differences between coastal and inland parts (Norwegian Meteorological Institute 1967, 1975).

Table 4 demonstrates the prevalence of herds with dye-test positive swine in the coastal and the inland zones. The difference 
between the coastal herds $(30 \%)$ and the inland herds (13\%) is striking $(\mathrm{P}=0.064)$. Climatic factors may perhaps explain this difference.

In their survey with the Toxoplasma skin test among 3000 Norwegian naval recruits, Vaage \& Midtvedt (1975) also found marked geographical differences. A low prevalence was found in the cold and dry south-eastern inland region and in the cold northern region (13.6 and $9.5 \%$, respectively) and a higher prevalence in the other regions (34.7 and $21.5 \%$ ).

A significant positive correlation between the weight of the swine carcass and the positive dye-test titre is shown in Table 1. This is in accordance with the results of Work (1971) in his work on swine in Denmark. He found $23 \%$ dye-test positive 6 month old swine and $50 \%$ positive among 3-4 year old swine. (The swine groups correspond to our groups 60 to $80 \mathrm{~kg}$ and $>140 \mathrm{~kg}$, respectively). Suzuki et al. (1961) reported a similar relationship in swine in Japan. In the present study a considerable difference in the prevalence between slaughter-pigs $(<100$ $\mathrm{kg}$ ) and young sows (100 to $140 \mathrm{~kg}$ ) was found (Table 1). Whether this is a normal situation or the young sows had experienced an epidemic is not known, and a closer study may be worth-while.

In this study, the swine weighing $\geq 140 \mathrm{~kg}$ had a lower prevalence of Toxoplasma antibodies than the swine weighing between 100 and $140 \mathrm{~kg}$. If there is a positive correlation between weight and age of the swine weighing $>100 \mathrm{~kg}$, the decreasing prevalence may be due to either an epidemiologic cohort effect or to a combined result of a cohort effect and the fact that the Toxoplasma antibodies are present only for a limited period after an infection. In this connection, changing of the animal's resistance to infection should be considered. Beverley (1974) claimed that swine may become serologically negative if some time elapses after an initial infection with Toxoplasma. He did not, however, discuss the possible serological effects of a reinfection. If the Toxoplasma antibodies in swine are short-lived, it may also explain the higher prevalence of titres $\geq 10$ among swine $<80 \mathrm{~kg}$ than among swine $\geq 80 \mathrm{~kg}$ as shown in Table 2 .

In the present survey, only dye-test titres $\leq 50$ have been found, and half of the sero-positive swine had dye-test titres of 4 . Dye-test titres up to 250 have been shown to correspond to the serological response to a primary infection with a small amount, from 4 to 150, of sporulated Toxoplasma oocysts (Durfee et al. 
1974). In the report of Work (1971) a dye-test titre of 250 is given as the highest titre, and it was found in $1.1 \%$ of the 528 swine. Taking into account the higher prevalence in Denmark, the differences between the distribution of positive sera in the 2 surveys are negligible. The distribution of positive titres in the study of Boch et al. (1964 b), however, shows a somewhat different pattern. Only $2.4 \%$ had titres $<4,3 / 4$ of the sera $(73.6 \%)$ had titres from 16 to 256 , and $12.2 \%$ had even higher titres. The chance of reinfection must be considerable when nearly all the individuals in the population seem to have contracted the disease, and the high titres may be an effect of reinfection with the parasite. Actually, in their work with artificial Toxoplasma infection in pigs, Boch et al. (1964 a), by reinfecting 18 pigs with Toxoplasma cysts, got a serological response parallelling the dyetest titres in their own survey among pigs in Germany.

As demonstrated in Table 3, Toxoplasma antibodies were not detected in swine from large herds $(\geq 300$ delivered swine per year), while the prevalence in smaller herds was about $20 \%$. No information about the farms and their management that may explain this difference was obtained. It should be noted, however, that larger farms usually have rationalized management and modern buildings and equipment. The swine and their feed are kept separated from other farm animals. This is important since the tendency of cats to defecate in the grain bins may be an actual way of transferring the parasite to swine. As far as sheep are concerned, this mode of transmission has been given attention by Penkert (1973) and Plant et al. (1974).

The presence of cats in an area seems to be of importance for the prevalence of Toxoplasma in both man and animals (Wallace 1969, Munday 1972, Waldeland 1977). Furthermore, Munday (1975) is of the opinion that not only the presence of cats, but also the density of the cat population may be of importance for Toxoplasma prevalence in a region. We have no data on the cat density in south-eastern Norway, but the coastal part of the region is the most populated in Norway with respect to humans. The inland region is more sparsely populated, and the distribution of the human population may be reflected in the cat density.

As the 60 to $80 \mathrm{~kg}$ swine in Part 1 and Part 2 were bred during different times of the year, seasonal variations in the incidence of Toxoplasma infections in swine could be revealed. This was not observed in the present work. 
The results of the parasitological examinations given in Table 5 show that Toxoplasma was recovered from the diaphragms of 20 of 33 dye-test positive swine, i.e. $61 \%$. This is somewhat in contrast to the results of Boch et al. (1964 b) and Work (1967) who isolated Toxoplasma from $9 \%$ of 488 swine (titre $\geq 4$ ) and $34 \%$ of 29 swine (titre $\geq 10$ ), respectively. These inconsistencies may be explained by our use of a more effective homogenizer and a more lenient digestion fluid than is prescribed in the original method by Jacobs et al. (1960). These changes may have given a better uncovering of present tissue cysts and a higher degree of survival of infective parasites during the digestion. This assumption is supported by the findings of Čatár et al. (1969), who recovered the parasite from all of 13 swine diaphragms minced with a homogenizer.

In the present work, Toxoplasma cysts were isolated from swine with a dye-test titre of 4 . This confirms the findings by Boch et al. (1964 b) and Čatár et al. While the parasite was recovered from only $39 \%$ of the swine with a titre of 4 , it was isolated from $80 \%$ of the swine with a titre of 10 and from all the swine with a titre of 50. This emphasizes the value of the dyetest as a diagnostic tool in work with porcine toxoplasmosis.

Toxoplasma strains virulent in mice have not been isolated in this work. However, 2 of the groups of mice died, but were not examined further. It is possible that these mice were inoculated with mouse-virulent Toxoplasma strains, which have been reported from similar studies on swine (Katsube et al. 1975).

The fact that the parasite was not recovered from dye-test negative swine, indicates that sero-negative swine seldom have latent infections, although Beverley (personal communication 1975) has isolated Toxoplasma from 2 pigs with a dye-test titre $<4$.

This investigation has shown that Toxoplasma may be isolated from about $2 / 3$ of the dye-test positive swine in southeastern Norway. Therefore, the feeding of meat-eating animals with unprepared meat or offal from swine should not be practised in order to avoid transmission of the parasite. Attention should be especially focussed on the feeding of cats, since this animal may shed Toxoplasma oocysts in the faeces after an infection.

The concumption of raw pork by humans may be a possible mode of transmitting toxoplasmosis to humans. Unprepared pork 
is seldom eaten in Norway, and this way of contracting the disease, is, therefore, not likely to happen in this country.

\section{REFERENCES}

Beverley, J. K. A.: Some aspects of toxoplasmosis, a world wide zoonosis. In Parasitic Zoonoses. ed.: E. J. L. Soulsby, Acad. Press, New York and London 1974.

Boch, J., M. Rommel \& K. Janitschke: Beiträge zur Toxoplasmose des Schweines. I. Ergebnisse künstlicher Toxoplasma-Infektionen bei Schweinen. (Report on toxoplasmosis in pigs. I. Results of artificial Toxoplasma infection in pigs). Berl. Münch. tierärztl. Wschr. 1964 a, 77, 161-167.

Boch, J., M. Rommel \& K. Janitschke: Beiträge zur Toxoplasmose des Schweines. II. Untersuchungen von Schlachtschweinen auf Toxoplasma-Infektionen. (Studies on toxoplasmosis in pigs. II. Research into Toxoplasma infection in slaughtering pigs). Berl. Münch. tierärztl. Wschr. 1964 b, 77, 244-247.

Čatár, G., L. Bergendi \& R. Holková: Isolation of Toxoplasma gondii from swine and cattle. J. Parasit. 1969, 55, 952-955.

Dubey, J. P., N. L. Miller \& J. K. Frenkel: The Toxoplasma gondii oocyst from cat feces. J. exp. Med. 1970, 132, 636-662.

Durfee, P. T., C. H. Ma, C. F. Wang \& J. H. Cross: Infectivity and pathogenicity of Toxoplasma oocysts for swine. J. Parasit. 1974, 60, $886-887$.

Farrell, R. L., F. L. Docton, D. M. Chamberlain \& C. R. Cole: Toxoplasmosis. I. Toxoplasma isolated from swine. Amer. J. vet. Res. 1952, 13, 181-185.

Feldman, H. A. \& L. T. Miller: Serological study of toxoplasmosis prevalence. Amer. J. Hyg. 1956, 64, 320-335.

Folkers, C. \& N. M. Perié: The prevalence of antibodies against Toxoplasma gondii in slaughter-pigs in the Netherlands. Trop. geogr. Med. 1963, 15, 268-270.

Hodges, J. L. \& E. L. Lehmann: Basic concepts of probability and statistics. Holden-Day, San Francisco 1970 , p. 332-344.

Jacobs, L., J. S. Remington \& M. L. Melton: A survey of meat samples from swine, cattle and sheep for the presence of encysted Toxoplasma. J. Parasit. 1960, 46, 23-28.

Katsube, Y., T. Hagiwara, K. Imaizumi \& K. Masuda: Latent infection of Toxoplasma in swine. Jap. J. vet. Sci. 1975, 37, 245-252.

Momberg-Jørgensen, H. C.: Toxoplasmose hos svinet. (Toxoplasmosis in swine). Nord. Vet.-Med. 1956, 8, 227-238.

Munday, B. L.: Serological evidence of Toxoplasma infection in isolated groups of sheep. Res. vet. Sci. 1972, 13, 100-102.

Munday, B. L.: Prevalence of toxoplasmosis in Tasmanian meat animals. Aust. vet. J. 1975, 51, 315-316.

Norwegian Meteorological Institute: Climatological Summaries for Norway: Standard Normals $1931-60$ of the Air Temperature in Norway, by Inger Bruun, Oslo 1967. 
Norwegian Meteorological Institute: Climatological Summaries for Norway: Preliminary Standard Normals 1931-60 of the Precipitation in Norway, Oslo 1975.

Penkert, R. A.: Possible spread of toxoplasmosis by feed contaminated by cats. J. Amer, vet. med. Ass. 1973, 162, 924 (letter to the editor).

Plant, J. W., N. Richardson \& G. G. Moyle: Toxoplasma infection and abortion in sheep associated with feeding of grain contaminated with cat faeces. Aust. vet. J. 1974, 50, 19—21.

Postdirektoratet: Postnummer. Fortegnelse over postnummer med tilhørende norske poststeder. (The Norwegian Postal Directorate. Postal numbers. List of postal numbers and respective Norwegian postal offices). Oslo 1972.

Rawal, B. D.: Toxoplasmosis in sheep in England. Lancet I, 1959, $881-882$.

Sabin, A. B. \& H. A. Feldman: Dyes as microchemical indicators of a new immunity phenomenon affecting a protozoan parasite (Toxoplasma). Science $1948,108,660-663$.

Siim, J. C.: Toxoplasmosis acquisita lymphonodosa. Thesis, Munksgaard, Copenhagen 1961, p. 62.

Suzuki, K., S. Ito \& J. Fujita: Serological survey of swine toxoplasmosis in Japan. Bull. nat. Inst. Anim. Hith 1961, 43, 22-26.

Vaage, L. \& T. Midtvedt: Epidemiological aspects of toxoplasmosis. II. The prevalence of positive toxoplasmin reactions in naval recruits from different parts in Norway. Scand. J. infect. Dis. $1975,7,218-221$.

Waldeland, H.: Toxoplasmosis in sheep. Epidemiological studies in flocks with reproductive loss from toxoplasmosis. Acta vet. scand. 1977, 18, 91-97.

Wallace, G. D.: Serologic and epidemiologic observations on toxoplasmosis on three Pacific atolls. Amer. J. Epidem. 1969, 90, 103111.

Weisstanner, T.: Nachweis von Toxoplasma gondii der Zwerchfellmuskulatur des Schweines. Ein Beitrag zur Epidemiologie der Toxoplasmose. (Isolation of Toxoplasma gondii in the diaphragm muscle of swine. A contribution to the epidemiology of toxoplasmosis). Path. et Microbiol. (Basel) 1969, 33, 44-56.

Work, K.: Isolation of Toxoplasma gondii from the flesh of sheep, swine and cattle. Acta path. microbiol. scand. 1967, 71, 296306.

Work, $K$.: Toxoplasmosis with special reference to transmission and life cycle of 'Toxoplasma gondii. Acta path. microbiol. scand. Section B, 1971, Suppl. no. 221, p. 12-13.

\section{SAMMENDRAG}

Toxoplasma gondii hos svin $i$ sørøstre deler av Norge.

Til sammen 407 svin slaktet ved Fellesslakteriet, Oslo, er testet for forekomst av Toxoplasma gondii antistoffer i serum ved bruk av 
dye-testen. Diafragma fra alle sero-positive og noen sero-negative svin er testet for forekomst av muse-infektive cyster.

Prevalensen av antistoffer var 10,1\%. Prevalensen steg med $\varnothing \mathrm{ken}-$ de slaktevekt, men med en nedgang for svin over $140 \mathrm{~kg}$. Bare dyetest titere opp til 50 ble påvist. Prevalensen av dye-test positive svin var høyere $\mathrm{i}$ små besetninger $(<300$ svin pr. år) enn i større $(>300$ svin pr. år). Prevalensen av besetninger med dye-test positive svin var høyere i området ved Oslofjorden enn lenger inne i landet. Insidensen av infeksjon med Toxoplasma gondii var den samme i sommer- og høstmånedene som i vinter- og vårmånedene. Toxoplasma ble påvist $\mathrm{i}$ diafragmamuskulatur fra omkring to tredjedeler av de sero-positive svinene. Parasitter ble isolert fra noen svin med titer $4 \mathrm{og}$ fra alle med titer 50. Toxoplasma ble ikke isolert fra sero-negative svin. Den epidemiologiske og næringsmiddelhygieniske betydning av toxoplasmose hos svin i Norge er diskutert med bakgrunn i de foreliggende resultatene.

(Received May 22, 1978).

Reprints may be requested from: The Department of Food Hygiene, Veterinary College of Norway, P. O. Box 8146, Oslo Dep., Oslo 1, Norway. 